\title{
Hubungan Antara Perhatian Orangtua Terhadap Kegiatan Belajar Siswa Dengan Kedisiplinan Siswa Di SMP Negeri Parakansalak-Sukabumi
}

\author{
Lisna Sujana ${ }^{1)}$, Endin Nasrudin ${ }^{2)}$, Ahmad Suryadi ${ }^{3)}$ \\ Sekolah Tinggi Agama Islam Sukabumi \\ Lisnasujana9@gmail.com ${ }^{1)}$ \\ Endinnasrudin26@gmail.com ${ }^{2}$ \\ Suryadiahmad68@gmail.com $\left.{ }^{3}\right)$
}

\begin{abstract}
Abstrak
Tujuan penelitian ini adalah untuk mengetahui perhatian orang tua terhadap belajar anak pada mata pelajaran Pendidikan Agama Islam di SMP Negeri Parakansalak Sukabumi, dan untuk mengetahui kedisiplinan siswa, serta untuk mengetahui hubungan perhatian orang tua terhadap belajar anak pada mata pelajaran Pendidikan Agama Islam dengan kedisiplinan siswa. Metode dalam penelitian ini adalah metode deskriptif. Menurut Winarno Surakhmad penyelidikan deskriftif adalah tertuju kepada pemecahan masalah yang ada pada masa sekarang, karena masalah yang diteliti adalah masalah yang hendak dipecahkan sekarang. Dari hasil analisa korelasi, diketahui ternyata antara Realitas perhatian orang tua terhadap kegiatan belajar anak dengan Kedisiplinan belajar siswa SMP Negeri Parakansalak berkorelasi tinggi. Kenyataan ini didasarkan pada harga hasil perhitungan koefisien korelasi sebesar 0,62. Harga sebesar ini berada pada interval antara 0,60 - 0,80, yaitu jatuh pada kualifikasi tinggi. Kemudian dari hasil perhitungan derajat pengaruh variabel $X$ terhadap variabel Y terbukti $22 \%$. Dengan demikian, masih ada sekitar $78 \%$ lagi faktor lain yang dapat mempengaruhi kedisiplinan belajar siswa SMP Negeri Parakansalak Kabupaten Sukabumi.
\end{abstract}

Kata Kunci: Perhatian Orangtua, Belajar, Disiplin

\begin{abstract}
The purpose of this study was to determine the attention of parents towards children's learning in Islamic Religious Education subjects at SMP Negeri Parakansalak Sukabumi, and to determine student discipline, as well as to determine the relationship between parents' attention to children's learning in Islamic Religious Education subjects with student discipline. The method in this research is descriptive method. According to Winarno Surakhmad, descriptive investigation is aimed at solving problems that exist in the present, because the problem being researched is a problem to be solved now. From the results of the correlation analysis, it is known that the reality of parents' attention to children's learning activities with the learning discipline of students at SMP Negeri Parakansalak has a high correlation. This fact is based on the calculated value of the correlation coefficient of 0.62. A price of this size is in the interval between $0.60-0.80$, i.e. it falls on a high qualification. Then from the results of the calculation of the degree of influence of variable $X$ on variable Y proved to be $22 \%$. Thus, there are still around $78 \%$ other factors that can affect the learning discipline of students of SMP Negeri Parakansalak, Sukabumi Regency.
\end{abstract}

Keywords: Parents' Attention, Learning, Discipline PENDAHULUAN yang terprogram pula. Akan tetapi dapat

Pendidikan merupakan usaha sadar orang dewasa melalui proses terencana dan terukur dengan tujuan pula pendidikan dilakukan tanpa terencana dan terprogram, akan tetapi menghasilkan output yang sama yaitu 
kedewasaan. Proses itulah kemudian yang dinamakan mendidik.

Mendidik harus dijalankan dengan penuh rasa tanggung jawab, sebab apabila mendidik tidak didasari dengan penuh rasa tanggung jawab, maka kemungkinan besar anak akan berkembang ke arah yang sebaliknya, yaitu tidak memanusiakan manusia dan tidak menempatkannya pada posisi dan fitrah sesungguhnya.

Setiap pendidikan tentu mempunyai tujuan yang hendak dicapai dan merupakan akhir yang harus ditempuh oleh setiap pendidik. Tujuan pendidikan tersebut bukan hanya mengisi bahwa dengan berbagai pengetahuan dan keterampilan belaka, akan tetapi harus diisi pengetahuan agama dan cara pengamalannya. Ilmu pengetahuan yang tinggi sebaiknya disukung dengankeyakinan khususnya daam agama akan memberikan kebahagiaan kepada pemiliknya.
Pendidikan Agama Islam

merupakan salah satu bidang studi yang harus diajarkan dari sekolah kanakkanak hingga perguruan tinggi, adapun tujuan pendidikan agama di sekolah ialah :

a. Menumbuhsuburkan dan mengembangkan serta membentuk sikap positif dan cinta terhadap agama dalam berbagai kehidupan supaya nantinya menjadi manusia yang bertaqwa kepada Allah.

b. Menumbuhkan dan membina keterampilan keagamaan dalam lapangan lingkungan hidup dan kehidupan serta dapat memahami dan menghayati ajaran Islam secara mendalam sehingga dapat digunakan sebagai pedoman hidup dan amalan atau perbuatan. 
Meskipun pendidikan agama

Islam telah dijadikan salah satu bidang studi di sekolah formal umum di Indonesia, akan tetapi masih jadi suatu persoalan bagi umat Islam karena materi dan waktunya masih terbatas. Menyadari betapa pentingnya peningkatan mutu pendidikan agama Islam, diperlukan perhatian orang tua (ibu dan bapak) yang mampu membimbing anaknya untuk menjadi anak yang sholeh yang dicita-citakan.

Sebagai orang tua sangat dianjurkan untuk selalu mengikuti segala ketentuan yang telah ditetapkan oleh Allah dan Rosul-Nya, sehingga apapun yang ia lakukan dalam proses pendidikan benar-benar mampu mewujudkan nilai ibadah, dengan kata lain tidak hanya sekedar melaksanakan tugas sebagai kepala keluarga saja, tetapi memberikan bimbingan dan perhatian kepada anak agar memiliki tingkah laku yang baik.
Selanjutnya Endin Nasrudin, menyatakan (2018:78) :

Semasa anak dalam periode perkembangan ini, ada baiknya bagi orang tua dan keluarganya untuk tidak menunjukan tingkah sosial yang mengganggu perkembangan emosionalnya. Jika dalam periode ini orang tua membentak dengan kata-kata kasar karena kesalahan kecil yang diperbuatnya, maka anak akan menganggap bentakan itu mencederai harga dirinya. Karena merasa bahwa harga dirinya telah dicederai, anak akan bereaksi.

Dalam dunia pendidikan, baik di rumah maupun di sekolah anak adalah fokus utama, karena anaklah yang akan dihantarkan dan dibantu agar mampu mempersiapkan masa depannya sendiri. Untuk melaksanakan kegiatan pendidikan diperlukan kesiapan dari anak (peserta didik) baik secara fisik maupun psikis. Pada kenyataannya tidak semua anak siap untuk dididik dan mampu berkembang sebagaimana diharapkan. Sebagian dari anak yang tidak mampu berkembang dengan wajar, justru menunjukkan keanehankeanehan dalam perkembangannya, 
bahkan bukan hanya merugikan dirinya sendiri akan tetapi dapat mengganggu ketentraman anak lain atupun lingkungannya.

Ada beberapa hambatan dalam perkembangan, sehingga perilaku yang ditampilkan anak tersebut berbeda dengan perilaku anak lain yang berada pada tingkat perkembangan yang sama, seperti melanggar tata tertib, bolos sekolah, berbohong, melawan dan berkata kasar, tawuran, menentang perintah serta perilaku lainnya.

Perilaku-perilaku tersebut di atas dapat dianggap sebagai masalah yang sering kali dihadapi oleh orang tua dan perlu mendapat perhatian, sebab kalau dibiarkan tentu akan menghambat kemajuan belajar peserta didik. Kesibukan orangtua turut serta dalam menurunnya perhatian mereka terhadap anak-anaknya. Dengan demikian, Peranan orang tua dalam keluarga sangat besar pengaruhnya, karena orang tua merupakan pendidik yang pertama dan utama dalam hidup dan kehidupan.

Sehubungan dengan hal tersebut di atas, tujuan penelitian adalah untuk mengetahuai Bagaimana perhatian orang tua terhadap kegiatan belajar anak pada mata pelajaran Pendidikan Agama Islam di SMP Negeri Parakansalak Kabupaten Sukabumi, bagaimana kedisiplinan siswa di SMP Negeri Parakansalak Kabupaten

Sukabumi, dan bagaimana hubungan perhatian orang tua terhadap belajar anak Pada mata pelajaran Pendidikan Agama Islam dengan kedisiplinan siswa di SMP Negeri Parakansalak Kabupaten Sukabumi.

\section{KAJIAN TEORI}

\section{Pengertian Perhatian}

Perhatian berhubungan erat dengan kesadaran jiwa terhadap sesuatu obyek yang direaksi pada suatu waktu. Terang tidaknya kesadaran kita terhadap sesuatu obyek tertentu tidak tetap, ada 
kalanya kesadaran kita meningkat (menjadi terang), dan ada kalanya menurun (samar-samar). Keadaan lapangan kesadaran dan kekuatannya tidak tetap pula, kadang-kadang luas dan kadang-kadang menjadi sempit. Hal itu tergantung pada pengerahan aktivitas jiwa terhadap obyek tersebut.

Taraf mampu meningkat jika jiwa kita dalam mereaksi sesuatu meningkat juga. Jika kesadaran kita naik karena sesuatu sebab, maka kita berada pada permulaan perhatian. Perhatian timbul dengan adanya pemusatan kesadaran kita terhadap sesuatu.

Membahas tentang perhatian tidak akan dapat dipisahkan dari psikologi perkembangan, karena perhatian merupakan aspek psikologi yang muncul seiring perkembangan fisiologis. Sebagaimana dinyatakan oleh. Endin Nasrudin (2018) dalam bukunya Psikologi Perkembangan berikut : "Pertumbuhan fisiologis anak di awal periode remaja terbilang pesat dan sudah mencakup semua aspek fisiologi orang dewasa. Perubahan yang paling terlihat ada dalam ukuran tubuh, proposrsi tubuh dan fungsi organ seksual”.

\section{Syarat-Syarat Perhatian}

\section{a. Inhibisi}

Inhibisi adalah pelarangan atau penyingkiran isi kesadaran yang tidak diperlukan, atau menghalang-halangi masuk ke dalam lingkungan kesadaran. Di sini jiwa harus membatasi lapangan kesadarannya, maka inhibisi didebut juga pembatasan lapangan kesadaran. Misalnya kita sedang giat bersiap diri untuk menempuh ujian. Supaya perhatian kita tetap terarah pada tugastugas sekolah/ujian, maka hendaknya ada inhibisi, artinya segala apa yang mungkin mengganggu harus dicegah jangan sampai masuk ke dalam suasana belajar kita. Ajakan teman untuk 
menonton, bacaan-bacaan yang tidak berguna perlu dikesampingkan. Oleh karena antisipasi berbagai cara dqan upaya agar berbagai gangguan tidak tercipta adanya.

\section{b. Appersepsi}

Appersepsi adalah suatu pengerahan dengan sengaja semua isi kesadaran, termasuk tanggapan, pengertian dan sebagainya yang telah dimiliki dan bersesuaian/berhubungan dengan obyek pengertian (Abu Ahmadi,1998:146). Dengan kata lain isi kesadaran yang menjadi sasaran perhatian tersebut ditempatkan di tengah-tengah tanggapan yang sesuai dengan obyek itu. Tujuannya supaya jiwa kita lebih memahami obyek yang menjadi sasaran. Misalnya kita mempelajari perkembangan Agama Islam di Indonesia. Supaya terjadi peristiwa appersepsi yang sebaikbaiknya, maka kita perlu mempunyai pengertian-pengertian tentang benda- benda peninggalan yang ada hubungannya dengan itu, seperti masjid dan lain sebagainya.

\section{c. Adaptasi (penyesuaian diri)}

Dalam gejala perhatian, organorgan kita, baik jasmani maupun rohani yang diperlukan untuk menerima obyek harus bekerja dengan sungguhsungguh (Kartini Kartono, 1993:135). Dalam memperhatikan sesuatu, organ kita menjadi giat menyesuaikan diri dengan tujuan/obyek.Jadi perlu ada penyesuaian diri antara subyek dan obyek. Peristiwa penyesuaian diri ini disebut adaptasi.

Kalau ketiga syarat tersebut (inhibisi,appersepsi dan adaptasi) dapat dipenuhi, maka cukuplah perhatian seseorang terhadap sesuatu, akibatnya pekerjaan yang dilakukan dapat berjalan baik tanpa gangguan.

Menurut Abu Ahmadi (1998:147), supaya perhatian kita tidak 
lekas kendur, terdapat hal-hal yang dapat membantu yaitu:

1) Adanya perasaan tertentu terhadap obyek tersebut. Apa yang kita perhatikan adalah sesuatu yang dipandang indah, baik luhur dan juga sebaliknya. Dengan kata lain, unsur perasaan membantu stabilitas perhatian kita; 2) Adanya kemauan yang kuat. Kalaupun perhatian asli terhadap sesuatu obyek tidak ada, tetapi obyek tersebut ternyata ada hubungan dengan kebutuhannya, maka dapat diharapkan bahwa kita akan mempunyai kemauan yang besar terhadap obyek itu. Dengan adanya kemauan yang kuat, perhatian kita tidak mudah kendur.

Dalam pandangan Islam,

sebagaimana Endin Nasrudin

kemukakan dalam bukunya Psikologi

kepribadian sebagai berikut :

Manusia memiliki potensi (daya atau kemampuan yang mungkin dikembangkan) beriman kepada Allah SWT. Sebab sebelum ruh (ciptaan) Allah dipertemukan dengan jasad manusia di rahim ibunya, ruh tersebut sudah mengalami persaksian primordial bahwa ia hanya mengakui Allah sebagai Tuhannya (2017).

Berdasarkan keterangan tersebut di atas, maka dapat disimpulkan bahwa perhatian berhubungan dengan kebutuhan-kebutuhan. Gejala perhatian juga dapat berhubungan dengan fungsifungsi jiwa yang lain.

\section{Definisi Belajar}

Sebagian orang beranggapan

bahwa belajar adalah semata-mata mengumpulkan atau menghafalkan fakta-fakta yang tersaji dalam bentuk informasi/materi pelajaran. Orang yang beranggapan demikian biasanya akan segera merasa bangga ketika anakanaknya telah mampu menyebutkan kembali secara lisan (verbal) sebagian besar informasi yang terdapat dalam buku teks atau yang diajarkan oleh guru.

Menurut Endin Nasrudin (2008) menyatakan bahwa : Belajar adalah suatu aktivitas untuk memperoleh ilmu pengetahuan serta menambah pengenalan seseorang terhadap sesuatu dengan menggunakan akal pikiran dan pengalaman.

Di samping itu, ada pula sebagian orang yang memandang 
belajar sebagai latihan belaka seperti yang tampak pada latihan membaca dan menulis. Berdasarkan persepsi semacam ini, biasanya mereka akan merasa cukup puas bila anak-anak mereka telah mampu memperlihatkan ketrampilan jasmaniah tertentu walaupun tanpa pengetahuan mengenai arti, hakikat, dan tujuan ketrampilan tersebut (Muhibbin Syah, 2000 ).

\section{Fase-Fase dalam Proses}

\section{Belajar}

Berbicara tentang belajar, berarti membahas tentang perubahan, dan perubahan merupakan proses, Karena belajar itu merupakan aktivitas yang berproses, sudah tentu di dalamnya terjadi perubahan-perubahan yang bertahap. Perubahan-perubahan tersebut timbul melalui fase-fase yang antar satu dengan lainnya bertalian secara berurutan dan fungsional.

Menurut Jerome S. Bruner yang dikutip Muhibbin Syah (2000) berpendapat bahwa dalam proses pembelajaran siswa menempuh tiga episode atau

fase, yaitu (a) fase informasi (tahap penerimaan materi); (b) fase transformasi (tahap pengubahan materi; dan (3) fase evaluasi (tahap penilaian materi).

1.Pengertian Pendidikan Agama Islam Pengertian Pendidikan Agama Islam menurut Marimba (2004) adalah bimbingan jasmani-rohani berdasarkan hukum-hukum agama Islam menuju kepada terbentuknya kepribadian utama menurut ukuran-ukuran Islam. Sedangkan Zakiyah Daradjat (1999) bahwa Pendidikan Agama Islam adalah usaha berupa bimbingan dan asuhan terhadap anak didik agar kelak setelah pendidikannya dapat memahami dan mengamalkan ajaran Islam serta menjadikannya sebagai pandangan hidup (way of life). 
Pendidikan Agama merupakan segi pendidikan yang utama yang mendasari semua segi pendidikan lainnya. Betapa pentingnya Pendidikan Agama Islam bagi setiap warga Negara Indonesia yang memeluk agama Islam. Terbukti dengan adanya peraturan pemerintah yang mengharuskan Pendidikan Agama Islam itu diberikan pada anak-anak Sekolah Dasar sampai dengan Perguruan Tinggi. Sama halnya dengan pendidikan yang lain, pendidikan agama juga menyangkut tiga aspek yaitu kognitif, afektif dan psikomotor. Hal ini berarti pendidkan agama bukan hanya sekedar memberi pengetahuan tentang keagamaan, justru yang lebih utama adalah membiasakan anak taat patuh menjalankan ibadah dan berbuat serta bertingkah laku di dalam kehidupannya sesuai dengan normanorma yang telah ditetapkan dalam agama.
1. Pengertia Disiplin Belajar Siswa

$$
\text { Kata "disiplin" merupakan kata }
$$

serapan dari bahasa asing, yaitu discipline

(bahasa Inggris) yang berarti tertib atau ketertiban. yang berarti cara pendekatan yang mengikuti ketentuan-ketentuan yang pasti dan konsisten, untuk memperoleh pengertian-pengertian dasar yang menjadi sasaran tadi.

Disiplin adalah tindakan yang teartur yangmana para pengikut itu tunduk dengan berdasarkan pada ajaranajaran pemimpinnnya atau suatu keadaan tertib dimana orang-orang yang tergabung dalam suatu organisasi patuh terhadap peraturan-peraturan yang telah ada dengan rasa senang hati.

Dewa Ketut Sukardi (1997 : 210) mengatakan bahwa :

Disiplin memiliki dua arti yang berbeda, tetapi keduanya mempunyai hubungan yang erat. Disiplin dibedakan ke dalam positif dan negatif. Dalam arti positif, disiplin adalah suatu rentetan aktivitas atau latihan yang berencana yang dianggap perlu atau 
penting untuk mencapai suatu tujuan tertentu. Sedangkan dalam arti negatif, disiplin adalah hukuman terhadap perilaku yang dianggap tidak diinginkan, karena telah melanggar peraturan atau tata tertib.

Dalam Buku Kamus

Ensiklopedi Nasional Indonesia

dikatakan, bahwa disiplin adalah suatu sikap yang menunjukkan kesediaan untuk menepati atau mematuhi dan mendukung ketentuan, tata tertib, peraturan, nilai serta kaidah yang berlaku (B. Setiawan, 1989). Disiplin bukanlah sesuatu yang dibawa sejak lahir. Perkembangannya pada anak sangat dipengaruhi oleh factor ajar (pendidikan). Disiplin selalu berkaitan dengan sikap, yaitu kesediaan bereaksi atau bertindak terhadap obyek atau keadaan tertentu. Sikap selalu dihadapkan pada perilaku untuk menerima dan menolak, berindak positif atau negaif.

Disiplin, selain berhubungan dengan penguasaan diri juga dengan rasa tanggung jawab. Orang yang disiplin cenderung patuh, mendukung dan mempertahankan tegaknya peraturan dan nilai yang berlaku, sikap ini menunjukkan adanya rasa tanggung jawab yang dapat berkembang menjadi sikapnya dalam kehidupan sehari-hari.

\section{METODOLOGI PENELITIAN}

Desain penelitian ini berawal dari masalah yang bersifat kuantitatif dan membatasi permasalahan yang ada pada rumusan masalah. Desain penelitian dijelaskan secara spesifik, jelas dan rinci yangmana ditentukan secara terarah sejak awal, menjadi pedoman penelitian.

Desain penelitian menghubungkan antara variabel $\mathrm{X}$ dan variabel Y. Penelitian ini terdiri dari dua variabel, yaitu variabel bebas $(\mathrm{X})$ yaitu Keteladanan Orang Tua dan Akhlaqul Karimah sebagai variabel terikat (Y). Keterkaitan antara keduanya digambarkan sebagai berikut : 


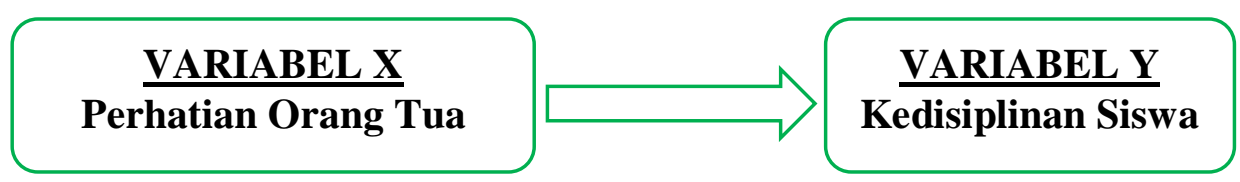

Variabel penelitian adalah obyek

prediktor, merupakan variabel

penelitian atau apa yang menjadi titik

yang dapat mempengaruhi

perhatian suatu penelitian. Variabel

perubahan dalam variabel

adalah merupakan suatu atribut yang

terikat dan mempunyai

mempunyai variasi tertentu dan perlu

dipecahkan dan ditetapkan oleh peneliti

untuk dipelajari dan kemudian

disimpulkan. Variabel bebas adalah

suatu variabel yang apabila dalam suatu

waktu berada bersamaan dengan

variabel lain, maka variabel lain itu

akan dapat berubah dalam

keragamannya. Sedangkan variabel

yang berubah karena pengaruh variabel

bebas disebut variabel terikat.

Adapun yang menjadi variabel dalam penelitian ini adalah perhatian orang tua dan kedisiplinan siswa, dimana variabelnya dibagi menjadi dua,

2. Variabel terikat (Dependent Variable) atau disebut variabel kriteria, menjadi perhatian utama (sebagai faktor yang berlaku dalam pengamatan) dan sekaligus menjadi sasaran dalam penelitian. Variabel terikat dalam penelitian ini adalah Kedisiplinan Siswa SMP Negeri Parakansalak Sukabumi. yaitu:

1. Variabel bebas (Independent Variable) yaitu variabel 


\section{HASIL DAN PEMBAHASAN}

a) Normalitas Data

Sebagaimanan telah dijelaskan terdahulu, kedua variabel berdistribusi normal, hal ini bisa dilihat untuk variabel $X=\chi^{2}$ hitung $(1,30)<\chi$ tabel $(11,3)$ untuk variabel $\mathrm{Y}=\chi^{2}$ hitung ( $0,49)<\chi$ tabel ( 11,3 ). Karena kedua variable berdistribusi normal maka penghitungannya menggunakan rumus sebagaimana telah disebutkan pada bab terdahulu.

\section{b) Persamaan regresi}

Dalam rangka mengetahui persamaan regresi menggunakan rumus $\mathrm{Y}=\mathrm{a}+\mathrm{bX}$. Berdasarkan hasil perhitungan, hasil yang diperoleh adalah $\mathrm{Y}=34+0,47 \mathrm{X}$ (perhitungan terlampir). Keadaan ini dapat disimpulkan bahwa setiap terjadi perubahan atau satuan pada variabel perhatian orang tua dalam kegiatan belajar anak ( $\mathrm{X}$ ), maka akan terjadi perubahan pada variabel kedisiplinan belajar siswa (Y), besar perubahan tersebut lebih kurang 0,47.

Berdasarkan perhitungan yang telah dilakukan, diketahui $\mathrm{F}$ hitung sebesar 1,11 sedangkan $\mathrm{f}$ tabel sebesar 2,355. dengan demikian $\mathrm{f}$ hitung lebih kecil dari pada $F$ tabel. Dapat disimpulkan bahwa data tersebut linear (perhitungan terlampir).

c) Menghitung harga koefisien

\section{korelasi}

Mengingat hasil perhitungan di atas, maka dapat diketahui bahwa kedua variabel berdistribusi normal dan berregresi linier. Untuk pengujian koefisien korelasinya menggunakan rumus korelasi. Dari perhitungan korelasi tersebut diperoleh nilai koefisien korelasi sebesar 0,62 ( perhitungan terlampir ). Nilai tersebut jika dikonsultasikan pada kriteria penilaian berada pada daerah interval $0,60-0,80$. ini bisa disimpulkan bahwa 
antara variabel $\mathrm{X}$ dan $\mathrm{Y}$ menunjuklan

korelasi tinggi.

d) Menghitung

signifikansi

korelasi

Sementara itu, pengajuan perhitungan signifikansi korelasi mempergunakan rumus T. dari perhitungan diperoleh thitung diperoleh 4,33 sedang $t$ tabel dengan taraf signifikasi 95\% sebesar 2,04. Dengan demikian $\mathrm{t}$ hitung $>$ dari $\mathrm{t}$ tabel. Keadaan ini dapat disimpulkan bahwa penelitian ini signifikan.

\section{e) Menghitung} derajat

\section{keterpengaruhan}

Berdasarkan perhitungan untuk menguji derajat pengaruh variabel $\mathrm{X}$ terhadap variabel $\mathrm{Y}$ ( perhitungan terlampir ), ternyata ada pengaruh sebesar 22\%. Hal ini berarti kedisiplinan belajar siswa dipengaruhi perhatian orang tua terhadap kegiatan belajar anak sebesar $22 \%$. Sedang sisanya sebesar $78 \%$ dipengaruhi oleh faktor lain.

\section{B. Pembahasan}

Penelitian ini dilakukan untuk menjawab rumusan penelitian yang sudah ditetapkan pada saat penelitian akan dilakukan, yaitu untuk mengetahui:

1. Perhatian orang tua terhadap kegiatan belajar anak pada mata pelajaran Pendidikan Agama Islam di SMP Negeri Parakansalak Kabupaten Sukabumi Berdasarkan hasil analisis data dengan menggunakan statistic deskriptif dapat dikemukakan bahwa Nilai Ratarata $($ Mean $)=56,13$, Median $=56,94$, Mode $=60,56 \quad$ Standar Deviasi=5,27, Range $=21$, Nilai Terrendah $=45$, dan Nilai tertinggi=66. Hal ini berarti bahwa Perhatian orang tua terhadap kegiatan belajar anak pada mata pelajaran Pendidikan Agama Islam di SMP 
Negeri Parakansalak Kabupaten

Sukabumi berada dalam katagori baik atau tinggi.

2. Kedisiplinan siswa di SMP Negeri Parakansalak Kabupaten Sukabumi

Berdasarkan hasil analisis data dengan menggunakan statistic deskriptif dapat dikemukakan bahwa: Nilai Ratarata $($ Mean $)=60,91, \quad$ Median $=60,72$, Mode $=65,82$ Standar $\quad$ Deviasi=5,534, Range $=16$, Nilai Terrendah $=52$, dan Nilai tertinggi=68. Hal ini berarti bahwa Kedisiplinan siswa di SMP Negeri Parakansalak Kabupaten Sukabumi berada dalam katagori baik.

3. Hubungan perhatian orang tua terhadap belajar anak Pada mata pelajaran Pendidikan Agama Islam dengan kedisiplinan siswa di SMP Negeri Parakansalak Kabupaten Sukabumi Berdasarkan hasil pengujian statistik yang telah diuraikan, maka dapat dikemukakan bahwa terdapat pengaruh yang signifikan hubungan perhatian orang tua terhadap belajar anak pada mata pelajaran Pendidikan Agama Islam dengan kedisiplinan siswa di SMP Negeri Parakansalak Kabupaten Sukabumi. Karena dari nilai hasil perhitungan, apabila dikonsultasikan pada skala penilaian yang sudah ditentukan berada pada daerah interval $0,60-0,80$. Hal ini dapat disimpulkan bahwa koefisien korelasi variebel $\mathrm{X}$ dan $\mathrm{Y}$ menunjukkan tinggi.

Selanjutnya mencari harga $\mathrm{t}$ daftar dengan menggunakan taraf signifikasi 95\% dan derajat kebebasan ( $\mathrm{db}=32-2=30)$ kemudian akan dicari harga t $0,95(30)=2,04$. Berdasarkan perhitungan, ternyata harga $\mathrm{t}$ hitung sebesar 4,36 lebih besar dari harga $\mathrm{t}$ daftar sebesar 2,04. Hal ini dapat diarrtikan bahwa korelasi antara 
variabel $\mathrm{X}$ dan variabel Y menunjukkan signifikan.

Besarnya pengaruh atau

Koefisen Determinasi (r2)/kekuatan hubungan yang diberikan variabel $\mathrm{X}$ (perhatian orangtua terhadap belajar anak) dengan Variabel Y (kedisiplinan Siswa) di SMP Negeri Parakansalak Kabupaten Sukabumi sebesar 0,78 atau $78 \%$. Dan ini menunjukkan bahwa ada sekira $22 \%$ faktor atau variabel lain yang mempengaruhi terhadap kedisiplinan siswa (Y) di sekolah.

\section{KESIMPULAN}

Setelah penulis mengadakan penelitian tentang perhatian orang tua terhadap kegiatan belajar anak hubungannya dengan kedisiplinan siswa pada mata pelajaran Pendidikan Agama Islam di SMP Negeri Parakansalak Kabupaten Sukabumi, maka dapatlah disimpulkan, bahwa :

1. Realitas perhatian orang tua terhadap kegiatan belajar anak
SMP Negeri Parakansalak

Kabupaten Sukabumi adalah

tinggi. Kenyataan dibuktikan

melalui penyebaran 15 item soal

angket kepada 32 siswa. Item angket tersebut mengacu kepada indikator-indikator kehadiran, perhatian, mencatat materi, bertanya dan mengerjakan tugas. Rata-rata yang diperoleh dari hasil jawaban responden adalah 4,03. Angka rata-rata sebesar ini berada pada kualifikasi tinggi, yaitu pada interval antara $3,5-4,5$.

2. Kedisiplinan belajar siswa SMP Negeri Parakansalak Bogor ternyata termasuk pada kualifikasi tinggi. Hal ini terbukti dengan skor yang diperoleh dari penyebaran angket kepada 32 responden yang mempertanyakan beberapa aspek kedisiplinan belajar siswa, yang meliputi (1) Kehadiran siswa; 
melaksanakan tugas dari guru;

(3) Belajar di rumah dengan

terjadwal; (4) Mengikuti

pelajaran dengan baik dan (5)

Mampu menggunakan waktu

luang. Hasil rata-rata dari

jawaban responden adalah 4,06.

Nilai sebesar ini ada pada interval

kualifikasi 3,5 - 4,5 yang berarti

kualifikasi tinggi.

3. Dari hasil analisa korelasi, diketahui ternyata antara Realitas perhatian orang

tua terhadap kegiatan belajar anak dengan Kedisiplinan belajar siswa SMP Negeri Parakansalak Kabupaten Sukabumi berkorelasi tinggi. Kenyataan ini didasarkan pada harga hasil perhitungan koefisien korelasi sebesar 0,62. Harga sebesar ini berada pada interval antara 0,60 - 0,80, yaitu jatuh pada kualifikasi tinggi. Kemudian dari hasil perhitungan derajat pengaruh variabel $\mathrm{X}$ terhadap variabel Y terbukti $22 \%$. Dengan demikian, masih ada sekitar $78 \%$ lagi faktor lain yang dapat mempengaruhi kedisiplinan belajar siswa SMP Negeri Parakansalak Kabupaten Sukabumi.

Penelitian yang telah dilakukan penulis, banyak memperoleh temuan baru yang bermanfaat baik bagi lembaga maupun bagi penulis serta dunia ilmu pengetahuan, oleh karena itu disampaikan beberapa saran berikut :

1. Perhatian orang tua terhadap kegiatan belajar anak SMP Negeri Parakansalak Kabupaten Sukabumi adalah tinggi. Oleh karena itu para orang tua dan guru, khususnya guru pendidikan agama Islam hendaklah selalu berupaya memepertahankan bahkan meningkatkan tanggung jawab dan profesionalismenya 
sehingga tujuan pembelajaran yang diharapkan tercapai.

2. Walaupun kedisiplinan belajar siswa SMP Negeri Parakansalak Bogor secara umum adalah baik. Namun demikian kepada orang tua dan para guru di sekolah harus tetap meningkatkan pembinaan kedisiplinan belajar, terutama perihal akhlak anak didiknya dengan cara memberikan contoh dan teladan yang baik. Sebab akhlak yang baik merupakan jati diri seorang muslim sejati.

\section{DAFTAR PUSTAKA}

Ahmadi, Abu. 1998. Psikologi Umum. Jakarta: Rineka Cipta.

Daradjat, Zakiah. 1999. Metodologi Pengajaran Agama Islam. Jakarta: Bumi Aksara.

Kartono, Kartini. 1999. Psikologi Perkembangan (Anak). Bandung: Mandar Maju.
Marimba, Ahmad D. 1999. Pengantar Filsafat Pendidikan Islam. Bandung: Alma'arif. Nasrudin, Endin. 2017. Psikologi Pembelajaran. Sukabumi: STAI Sukabumi Publishing.

Nasrudin, Endin. 2018. Psikologi Perkembangan. Sukabum: STAI Sukabumi.

Setiawan B. 2000. Disiplin, Ensiklopedia Nasional Indonesia. Jakarta: Adi Pustaka.

Sukardi, D.K. 1998. Bimbingan dan Konseling. Bandung: Bina Aksara.

Syah, Muhibbin. 2000. Psikologi Pendidikan (Suatu Pendekatan Baru). Bandung: Remaja Rosdakarya. 